\title{
Early switch therapy from ceftriaxone to ampicillin in an immunocompromised patient with Listeria monocytogenes septicemia and meningitis
}

\section{İmmün sistemi baskılanmış hastada Listeria monocytogenes'e bağlı septisemi ve menenjitin tedavisinde seftriaksondan amiplisine erken geçiş}

\author{
Gülșen HAZIROLAN', Gülçin DiZMAN²
}

\begin{abstract}
ÖZET
Listeria monocytogenes is an important pathogen that may cause infection in the elderly and in immunocompromised patients with predisposing conditions. It can be an important cause of lifethreatening bacteremia and meningoencephalitis in immunocompromised individuals. In this report, it was described a case of sepsis and menegititis caused by $L$. monocytogenes in a 39-year-old female with adenoid cystic carcinoma of the larynx. L. monocytogenes identification was performed at the species level using matrix-assisted laser desorption ionization-time of flight mass spectrometry (MALDI-TOF MS, Bruker Daltonics, Germany). The patient was treated with an early switch therapy from ceftriaxone to ampicillin. This report indicates that early detection and treatment of Listeria sepsis and meningitis are important to obtain a better prognosis.
\end{abstract}

Anahtar Kelimeler: Listeria monocytogenes, meningitis, septicemia, MALDI TOF MS

\section{ABSTRACT \\ Listeria monocytogenes, yașlılarda ve} predispozan koșulları olan bağıșıklık sistemi baskılanmış hastalarda enfeksiyona neden olabilecek önemli bir patojendir. Bu bakteri, bağıșıklık sistemi baskılanmıș kișilerde hayatı tehdit eden bakteriyemi ve meningoensefalitin önemli bir nedeni olabilir. Bu raporda, larenks adenoid kistik karsinomu olan 39 yașındaki bir kadın hastada $L$. monocytogenes'in etken olduğu sepsis ve menenjit olgusu tanımlandı. L. monocytogenes'in tür düzeyinde tanımlanması matrix-assisted laser desorption and ionization timeof-flight mass spectrometry (MALDI-TOF MS, Bruker, Almanya) ile yapıldı. Hasta tedavide seftriaksondan ampisiline erken geçiş ile tedavi edildi. Bu rapor, Listeria sepsis ve meninjitinin erken saptanmasının ve tedavisinin, daha iyi bir prognoz elde edilmesindeki önemini ișaret etmektedir.

Key Words: Listeria monocytogenes, menenjit, sepsis, MALDI TOF MS

${ }^{1}$ Hacettepe Üniversitesi, Tıp Fakültesi, Tıbbi Mikrobiyoloji Anabilim Dalı, Ankara

${ }^{2}$ Hacettepe Üniversitesi, Tıp Fakültesi, İnfeksiyon Hastalıkları ve Klinik Mikrobiyoloji Anabilim Dalı, Ankara

İletişim / Corresponding Author : Gülşen HAZIROLAN

Hacettepe Üni. Tıp Fakültesi, Tıbbi Mikrobiyoloji Anabilim Dalı, Sıhhıye 06100 Ankara - Türkiye

E-posta / E-mail : drgulsencetin@yahoo.com

Geliş Tarihi/Received : 23.12.2019

Kabul Tarihi / Accepted : 02.07.2020

DOI ID : 10.5505/TurkHijyen.2020.04127

Hazırolan G, Dizman G. Early switch therapy from ceftriaxone to ampicillin in an immunocompromised patient with Listeria monocytogenes septicemia and meningitis. Turk Hij Den Biyol Derg, 2020; 77(4): 493-496 


\section{INTRODUCTION}

Listeria monocytogenes is a facultatively anaerobic non-spore-forming gram-positive bacterium. It is known to be responsible for severely invasive disease and it can cause sepsis, meningitis, and encephalitis (1). L. monocytogenes infection occurs predominantly in the following populations: elderly people, pregnant women, newborns, and immunodeficient patients; patients with chronic liver disease, malignant hemopathies, and diabetes; patients on chronic hemodialysis; and, less frequently, healthy individuals (2). The main route of transmission is confirmed to be through the consumption of contaminated food and via vertical transmission from mother to child (3). L. monocytogenes has the ability to cross three significant barriers in humans, such as the intestinal barrier, the blood-brain barrier and the fetoplacental barrier. It can invade normally nonphagocytic cells such as endothelial cells, enterocytes, and fibroblasts, utilizing certain surface invasion proteins, of which internalin $A(\operatorname{In}(\mathrm{A})$ and internalin $B(\operatorname{In}(B)$ are the best studied (4). Meningitis caused by this bacterium is associated with high mortality rates (5). Diagnosis of meningitis caused by $L$. monocytogenes is a challenge due to the absence of typical clinical symptoms (6). L. monocytogenes is considered susceptible to a wide range of antibiotics, such as ampicillin, tetracyclines, erythromycin, and gentamicin. However, most strains of $L$. monocytogenes exhibit intrinsic resistance to cefotaxime, cefepime, fosfomycin, oxacillin, and lincosamides (7). In this report, we describe a case of sepsis and meningitis caused by $L$. monocytogenes which developed after chemotherapy and radiotherapy for metastatic adenoid cystic carcinoma of the larynx. Patient was treated with an early switch therapy from ceftriaxone to ampicillin.

\section{CASE REPORT}

A 39-year-old female with diffuse metastatic adenoid cystic carcinoma presented to the Emergency Department of Hacettepe University Hospital because of fever and general weakness in June 2019. Patient was evaluated for infectious diseases because of high fever. Lumbar puncture (LP) was recommended as a preliminary diagnosis of central nervous system infection. Cranial magnetic resonance imaging (MRI) showed diffuse intracranial metastasis and edema. LP could not be performed due to widespread intracranial metastases. All diagnostic procedures and the treatment were performed after the informed consent had been obtained orally. Empiric acyclovir $(3 \times 10 \mathrm{mg} / \mathrm{kg})$ and ceftriaxone $(2 \times 2$ grams) were started. One set (one aerobic and one anaerobic bottles) of blood sample was taken for the culture. Bactec Plus Aerobic/F and Bactec Lytic (BD Diagnostic, USA) aerobic and anaerobic blood culture bottles were incubated in a Bactec FX instrument (BD Diagnostic, USA). Anaerobic blood culture bottle had a positive signal at the 19th hour of incubation. Microscopy of Gram-stained smears was performed for the positive blood culture bottle. Gram-positive rods were observed and clinicians were informed. Subcultures were performed in $\% 5$ sheep blood agar (BD, USA), schaedler agar (BD, USA), chocolate agar (BD, USA) and MacConkey agar(BD, USA), and incubated in aerobic (\%5 sheep blood agar, chocolate agar and MacConkey agar) and anaerobic (schaedler agar) conditions. Semi-transparent colonies having beta-hemolysis were obtained from the aerobic culture at the end of 24 hours incubation, and Gram staining of the colonies showed gram-positive rods. The isolate was a catalase-positive, oxidasenegative, CAMP-positivite. Semi-solid motility test medium was used for detecting bacterial motility activity (BD, U.S.A) and the isolate was motile bacterium. Matrix-asssisted laser desorption/ ionization-time of flight mass spectrometry (Bruker, Germany) was used for the identification. The isolate was identified at the species level with a score of 
$\geq 2.0$ as L. monocytogenes. Antibiotic susceptibility test was performed by gradient test according to the European Committee on Antimicrobial Susceptibility Testing (EUCAST) guidelines. Minimum inhibitory concentration of ampicillin, penicillin, meropenem, erythromycin, and trimethoprim/sulfamethoxazole were $0.38 \mu \mathrm{g} / \mathrm{ml}, 0.38 \mu \mathrm{g} / \mathrm{ml}, 0.19 \mu \mathrm{g} / \mathrm{ml}, 0.50 \mu \mathrm{g} /$ $\mathrm{ml}, 0.032 \mu \mathrm{g} / \mathrm{ml}$ respectively. L. monocytogenes was susceptible to all tested antibiotics. Due to detection of $L$. monocytogenes from blood culture at the $48^{\text {th }}$ hour of treatment, initial acyclovir and ceftriaxone therapy was changed to ampicillin (6x2 grams). Fever response was obtained at the 48th hour of the ampicillin treatment and CRP value decreased to $1.55 \mathrm{mg} / \mathrm{dl}$. Control blood culture showed absolutely no growth. The patient was discharged after 21 days of ampicillin treatment with the diagnosis of Listeria bacteremia and a preliminary diagnosis of Listeria meningitis.

\section{DISCUSSION}

An empirical therapy for bacterial meningitis, generally third-generation cephalosporins, is always applied at an early stage when bacterial meningitis is suspected. However, this treatment option does not cover $L$. monocytogenes. Cephalosporins, which are effective for some bacterial agents of meningitis, are ineffective against $L$. monocytogenes. This is important to remember in the empiric selection of drugs for pyogenic meningitis. Ampicillin is the preferred agent, resistance to this agent has not been observed $(8,9)$. Listeria meningitis should be considered in cases that have immunosuppression and do not improve following first-line treatment with extended-spectrum cephalosporins. Unfortunately, adequate therapy might be delayed in our case, since initial empirical therapy was not adjusted to include ampicillin. Ampicillin should be added to initial empirical therapy especially for Listeria suspicion due to the risk factors. In this report, we described a case of meningitis and bacteremia caused by $L$. monocytogenes in a cancer patient. MALDI-TOF MS has become a standard tool for rapid and reliable microbial identification in clinical laboratories. Rapid and reliable identification of $L$. monocytogenes using MALDI-TOF MS allows a rapid detection of bacteria that cause a life-threatening infection and also provide accurate therapy. When L. monocytogenes was isolated from blood culture, antibiotic treatment was switched from ceftriaxone to ampicillin immediately, and the patient was cured. It is very important to adjust the appropriate antibiotic therapy as soon as possible once Listeria is highly suspected or confirmed by a culture. We encountered a case with sepsis and meningitis caused by $L$. monocytogenes which developed after chemotherapy and radiotherapy for metastatic adenoid cystic carcinoma of the larynx. Early management of sepsis and meningitis, by performing rapid diagnostic methods and by administration of adequate antimicrobial therapy, can be defined as life-saving circumstances in patients with listeriosis. 


\section{KAYNAKLAR}

1. Orsi RH1, Wiedmann M. Characteristics and distribution of Listeria spp., includingListeria species newly described since 2009. Appl Microbiol Biotechnol, 2016; 100(12): 5273-87.

2. Lorber B. Listeriosis. Clin Infect Dis, 1997; 24(1): $1-1$.

3. Wang HL, Ghanem KG, Wang P, Yang $\mathrm{S}$, Li TS. Listeriosis at a tertiary care hospital in beijing, china: high prevalence of nonclustered healthcare-associated cases among adult patients. Clin Infect Dis, 2013; 56(5): 666-76.

4. Douglas A. Drevets, Michael S. Bronze. Listeria monocytogenes: epidemiology, human disease, and mechanisms of brain invasion. FEMS Microbiol Immunol, 2008; 53(2): 151-65.

5. Stavru F, Archambaud C, Cossart P. Cell biology and immunology of Listeria monocytogenes infections: novel insights. Immunol Rev, 2011; 240(1): 160-84.
6. Jing-Jing Liang, Xiao-Yan He, Hong Ye. Rhombencephalitis caused by Listeria monocytogenes with hydrocephalus and intracranial hemorrhage: A case report and review of the literatüre. World J Clin Cases, 2019; 4(7): 538-7.

7. Morvan A, Moubareck C, Leclercq A, HervéBazin M, Bremont S, Lecuit M. Antimicrobial resistance of Listeria monocytogenes strains isolated from humans in France. Antimicrob Agents Chemother, 2010; 54(6): 2728-31.

8. Heyderman RS. Early management of suspected bacterial meningitis and meningococcal septicaemia in immunocompetent adultssecond edition. J Infect, 2005; 50(5): 373-74.

9. Tunkel AR, Hartman BJ, Kaplan SL, Kaufman BA, Roos KL, Scheld WM, Whitley RJ. Practice guidelines for the management of bacterial meningitis. Clin Infect Dis, 2004; 39(9): 126784. 